\title{
FOOD CONSUMPTION AND NUTRITIONAL STATUS OF BRESTFEEDING MOTHERS AND INFANTS
}

\author{
(Konsumsi Pangan dan Status Gizi Ibu Menyusui dan Bayinya)
}

Eddy S. Mudjajanto ${ }^{1}$ and Dadang Sukandar ${ }^{1}$

\begin{abstract}
ABST RAK
Penelitian ini bertujuan untuk mengidentifikasi kondisi sosial ekonomi, konsumsi ibu menyusui dan bayi, frekuensi konsumsi pangan ibu menyusui serta menganalisis status gizi ibu menyusui dan bayi. Desain penelitian ini menggunakan cross-sectional dengan sampel ibu menyusui. Sampel yang diambil sebanyak 100 orang ibu menyusui. Pemilihan sampel dilakukan secara acak berlapis (stratified random sampling). Penelitian ini dilakukan di dua kecamatan di Kabupaten Cianjur pada tahun 2006-2007. Data yang dikumpulkan meliputi karakteristik sosial ekonomi keluarga ibu menyusui, konsumsi dan frekuensi konsumsi pangan ibu menyusui dan bayi, status gizi ibu menyusui serta data antropometri bayi yang digunakan untuk menentukan status gizi bayi. Data karakteristik sosial ekonomi keluarga ibu menyusui, konsumsi dan frekuensi konsumsi bayi diperoleh melalui wawancara dengan menggunakan kuesioner. Data antropometri bayi diperoleh melalui pengukuran yang dilakukan selama penelitian berlangsung. Data hasil wawancara dan pengukuran dientri menggunakan software excel. Data dianalisis dengan SAS (Statistical Analysis System) dan menggunakan uji Regresi. Hasil penelitian ini menunjukkan bahwa konsumsi energi dan protein ibu menyusui secara rata-rata hanya memenuhi $60 \%$ dan $87 \%$ dari angka kecukupan gizi yang dianjurkan (RDA). Konsumsi energi dan protein bayi secara rata-rata sudah memenuhi $100 \%$ dan $106 \%$ dari angka kecukupan gizi yang dianjurkan (RDA). Prevalensi ibu menyusui pada kategori thin dan overweight masing-masing sebesar $10 \%$ dan $16 \%$ Pada bayi, prevalensi dari underweight, stunted dan wasted yaitu sebesar $8.5 \%, 45.7 \%$ dan $9.6 \%$
\end{abstract}

Keywords : konsumsi, frekuensi makan, status gizi

\section{INTRODUCTION}

\section{Background}

Nation building is basically a governmental effort together with its people to improve national welfare. A successful development of a nation is determined by the available human resources. High-quality of human resources are characterized by a strong physical body, resilient mind, good health and mastery of science and technology. One indicator to measure the quality of human resources is human development index (HDI). Three determinant major factors of HDI are education, health and economy. The three factors are closely related to the nutritional status of a community. Malnutrition leads to a reduced quality of human resources. A lack of nutrition will cause a slow-down of physical growth, mental development, intelligence, decreased productivity, increased diseases and deaths (Azwar, 2004).

\footnotetext{
${ }^{1}$ Lecturer on Department of Community Nutrition, Faculty of Human Ecology, Bogor Agricultural University (IPB).
}

Every individual has right to have an acces to adequate, safe and nutritious food so that they are free from hunger. Sufficient food consumption in household will have impact on the nutritional status of the household. Good nutritional status must be supported by adequate food consumption. Maxwell and Frankenberger (1992) stated that the nutritional status was affected by food consumption.

The nutritional status of babies influenced by theirs mother. Food consumption of babies depend so much on breastfeeding and supplemental feeding. The breast milk is important for nutrients for babies. Breast milk not only sufficient nutrition for babies but also other factors such as hormone, antibody and growt factors (Walker, 1988).

\section{Goals and Objectives}

The objectives of this study were to identify social and economic condition, food consumption and to analyze the nutritional status of breastfeeding mothers and infants. 


\section{METHODS}

\section{Design}

This study was a cross-sectional design and conducted in Cianjur Regency at 20062007.

\section{Sampling}

The populations studied in this research were breastfeeding mothers and 100 breastfeeding mothers were taken. Samples were taken through stratified random sampling. Cianjur District was selected since there were variations in nutrition program implemented and variations in achieving the program objectives (Personal Communication with Staff of Health Services, Cianjur, February 10, 2006). The two subdistricts were chosen to increase heterogeneity of samples, so that the performance of nutrition program was truly represented by the selected samples.

\section{Data collection}

Data collection consisted of food consumption, food frequency, and nutritional status. The data was collected through questionnaires, the food consumption was measured using a recall methode of $1 \times 24$ hour.

\section{Data Analysis and Management}

Processing was include editing questionnaires, coding, arrangement of file structure, data entry, editing files, raising variables, combining and separating files. Data processing and analysis used Excel and Statistical Analysis System.

The estimations of means, standard deviation, minimum and maximum values made for all quantitative variables. The estimation of proportion has been conducted for all categorized qualitative and quantitative variables. The predicted results have been presented in the forms of tables and diagrams.

\section{RESULTS}

\section{Food Consumption of Breastfeeding Mothers}

\section{Consumption and Nutrition Adequacy}

Energy. Energy consumption and nutritional adequacy level are presented at Tables 1 and 2. It can seen from Table 1 that the average energy consumption of breastfeeding mothers is $1744 \mathrm{kcal} / \mathrm{day}$; however, this only fulfills $60 \%$ of the recommended dietary al- lowances (RDA) (Table 2). As it occurs among the pregnant women, this low energy consumption of breastfeeding mothers is found in various researches on breastfeeding mothers. According to Arisman (2004), if the energy intake by the women is less than $2700 \mathrm{kcal} / \mathrm{day}$, it indicates that they lack calcium, magnesium, zinc, vitamin B6 and pholate.

Table 1. Statistics of Nutrients Consumption of Breastfeeding Mothers

\begin{tabular}{|l|r|r|}
\hline \multirow{2}{*}{ Nutrients } & \multicolumn{2}{|c|}{$\mathbf{n = 1 0 0}$} \\
\cline { 2 - 3 } & \multicolumn{1}{|c|}{ Mean } & \multicolumn{1}{c|}{ Std } \\
\hline Energy $(k c a l)$ & 1744 & 521 \\
\hline Protein $($ gram) & 52.8 & 24.2 \\
\hline Vitamin A $(\mu \mathrm{gRE})$ & 977 & 640 \\
\hline Vitamin C $(\mathrm{mg})$ & 57 & 22 \\
\hline Vitamin B1 $(\mathrm{mg})$ & 0.68 & 0.14 \\
\hline Calcium $(\mathrm{mg})$ & 746 & 339 \\
\hline Phosfor $(\mathrm{mg})$ & 741 & 347 \\
\hline Iron $(\mathrm{mg})$ & 26.3 & 16.8 \\
\hline
\end{tabular}

Table 2. Statistics of Nutritional Adequacy of Breastfeeding Mothers

\begin{tabular}{|l|r|r|}
\hline \multirow{2}{*}{ Nutrients } & \multicolumn{2}{|c|}{$\mathbf{n = 1 0 0}$} \\
\cline { 2 - 3 } & \multicolumn{1}{|c|}{ Mean } & \multicolumn{1}{c|}{ Std } \\
\hline Energy (\%) & 62.4 & 18.7 \\
\hline Protein (\%) & 87.6 & 40.3 \\
\hline Vitamin A (\%) & 117.5 & 76.0 \\
\hline Vitamin C (\%) & 71.8 & 28.1 \\
\hline Vitamin B1 (\%) & 52.4 & 10.9 \\
\hline Calcium (\%) & 82.4 & 38.0 \\
\hline Phosfor (\%) & 104.6 & 48.1 \\
\hline Iron (\%) & 96.9 & 60.2 \\
\hline
\end{tabular}

Protein. Proteins as the developing substances of new tissues play an important role in all life aspects starting from babies, underfive-year-old children, teenagers, women who are pregnant and breastfeeding to people who are in recovery period (Susmaji, 2004). Consumption and protein adequacy level are presented at Tables 1 and 2 . From Table 1, it can be seen that the average protein consumption of breastfeeding Mothers is $52.8 \mathrm{~g} /$ day. As a whole, this only fulfills $80 \%$ of the recommended protein level. This protein usually comes from salty fish.

Calcium. Calcium is crucial for the breast milk. The consumption of calcium of the women is relatively low i.e. only 746 $\mathrm{mg} /$ day, only reaching $80 \%$ of the required calcium level (Table 2). In fact, calcium con- 
tained in the mothers' milk is more easily absorbed by babies compared to other food substances so that their calcium need can be supplied by the calcium from the breast milk. Anchovies are frequently consumed by women to obtain their calcium possibly because they are available in the markets and more affordable than other animal protein sources.

Phosphor. The average consumption of phosphor is $741 \mathrm{mg} /$ day (Table 1), which already fulfills $105 \%$ of the recommended phosphor level (Table 2). This consumption varies among the women as shown by the standard deviation of $347 \mathrm{mg} /$ day.

Iron. From Table 1, it can be seen that the average iron consumption is $26.3 \mathrm{mg} /$ day. With the assumption of $10 \%$ iron absorption, the average adequacy level already reaches $97 \%$.

Vitamin A. The average consumption of vitamin A for the women is 977 ugRE, fulfilling $117 \%$ of the recommended level. This consumption varies among the women as shown by standard deviation of $640 \mathrm{mg} /$ day.

Vitamin C. The average consumption of vitamin $C$ for the women is $57 \mathrm{mg} /$ day fulfilling $70 \%$ of the recommended level. This consumption is relatively the same among the women as shown by standard deviation of 22 $\mathrm{mg} /$ day. This low consumption may be caused by a less intake of vegetables and fruits containing a lot of vitamin $C$.

Vitamin B1. The average consumption of vitamin B1 among women is $0.6 \mathrm{mg}$ fulfilling only $52 \%$ of the recommended level. This consumption is also relatively the same among the women as shown by standard deviation of 0.14 $\mathrm{mg} /$ day. This vitamin is frequently found in cereal products such as rice, bread, noodle, etc. (Arisman, 2004).

\section{Food Consumption Frequency}

Frequency of Staple Food. This frequency is presented to see the women's eating habits or patterns in the research area. Table 1 shows that one type of cereals and secondary food crops that they frequently consume every day or 2 times a day is rice. Rice has been the staple food for Indonesian population. Corn, cassava, taro, sweet potato and potato are rarely consumed by the women.

Consuming rice is the common eating pattern among Indonesian communities. They have consumed rice since the ancient period, and this habit lasts until now. There are various factors influencing the communities in consuming rice such as the flavor, socio culture, nutritional value, availability and affordability (Ariani, 1998).

Rice is mostly purchased, only a few grow rice and obtain it from their neighbors. Cassava and sweet potato are mostly given by other people.

Frequency of Animal Food. The types of foods as animal protein sources such as meat, fish and egg, which are consumed almost every day with the frequency of 0.6 times per day or 3 to 4 times per week by the $90 \%$ breastfeeding mothers, include salty fish, eggs, and milk (Table 4). This might be due to their availability, especially salty fish, eggs of layer chicken, and milk are easier to obtain than other animal protein sources.

The reasons for the higher consumption of eggs of layer chicken than that of eggs of kampong chicken are that they are cheaper and more easily available (Erwidodo, Ariani, Purwoto, 1997). Chicken meat and pindang (preserved fish) fish are usually consumed once a week. Other types of animal protein sources are rarely consumed. These kinds of foods are mostly purchased, and only a few of them such as beef/lamb meat and fresh water fish are given by other people.

Table 3. Statistics of Staple Food Consumption Frequency of Breastfeeding Mothers

\begin{tabular}{|l|c|r|r|r|r|}
\hline \multirow{2}{*}{\multicolumn{1}{c|}{ Kinds of Major Food }} & \multirow{2}{*}{$\mathbf{n}$} & \multirow{2}{*}{$\%$} & \multicolumn{3}{c|}{$\begin{array}{c}\text { Frequency of Consumption } \\
\text { (times per) }\end{array}$} \\
\cline { 5 - 7 } & & & \multicolumn{1}{c|}{ Month } & \multicolumn{1}{c|}{ Week } & \multicolumn{1}{c|}{ Day } \\
\hline Rice (Oryza sativa) & 100 & 100.0 & 76.7 & 17.7 & 2.5 \\
\hline Corn (Zea mays) & 80 & 80.0 & 2.4 & 0.6 & 0.1 \\
\hline Cassava (Manihot utilissima) & 86 & 86.0 & 2.4 & 0.6 & 0.1 \\
\hline Sweet Potato (Ipomoea batatas) & 80 & 80.0 & 1.8 & 0.4 & 0.06 \\
\hline Taro (Colocasia esculenta) & 34 & 34.0 & 0.2 & 0.04 & 0.01 \\
\hline Potato (Solanum tuberosum) & 2 & 2.0 & 0.2 & 0.05 & 0.01 \\
\hline
\end{tabular}


Table 4. Statistics of Animal Food Consumption Frequency of Breastfeeding Mothers

\begin{tabular}{|l|r|r|r|r|r|}
\hline \multirow{2}{*}{\multicolumn{1}{|c|}{ Kinds of Animal Food }} & \multirow{2}{*}{$\mathbf{n}$} & \multirow{2}{*}{$\%$} & \multicolumn{3}{c|}{$\begin{array}{c}\text { Frequency of Consumption } \\
\text { (times per) }\end{array}$} \\
\cline { 5 - 6 } & & & \multicolumn{1}{c|}{ Month } & \multicolumn{1}{c|}{ Week } & \multicolumn{1}{c|}{ Day } \\
\hline Salty fish & 95 & 95.0 & 20.1 & 4.6 & 0.7 \\
\hline Layer Chicken's Egg & 99 & 99.0 & 15.7 & 3.6 & 0.5 \\
\hline Milk & 66 & 66.0 & 14.0 & 3.2 & 0.5 \\
\hline Ikan Pindang (Preserved fish) & 89 & 89.0 & 7.6 & 1.7 & 0.2 \\
\hline Chicken Meat & 99 & 99.0 & 6.1 & 1.4 & 0.2 \\
\hline Fresh Water Fish & 82 & 82.0 & 3.6 & 0.8 & 0.1 \\
\hline Sea Water Fish & 54 & 54.0 & 2.3 & 0.5 & 0.1 \\
\hline Salty Egg & 48 & 48.0 & 1.8 & 0.4 & 0.1 \\
\hline Kampong Chicken's Egg & 34 & 34.0 & 1.7 & 0.4 & 0.1 \\
\hline Beef/Goat Meat & 88 & 88.0 & 1.2 & 0.3 & 0.04 \\
\hline Chicken Nugget & 12 & 12.0 & 0.6 & 0.1 & 0.02 \\
\hline
\end{tabular}

Frequency of Legumes. Nuts are vegetable protein sources; nevertheless, they are not consumed every day by the breastfeeding mothers (Table 5). Tofu and fermented soybean (tempeh) are consumed 3 to 4 times a week by $90 \%$ breastfeeding mothers because they are easily obtained and cheap. Most tofu and soybean products are processed by frying them or mixing them with vegetables, or cooking with soybean ketchup. Oncom (traditional Indonesian fermented food), peanut and mung-bean are consumed once a week. Other types of legumes are rarely consumed. These types of foods are $100 \%$ purchased. Almost no women grow the legumes or obtain them from other people.

Frequency of Leaf Vegetable. Vegetables are mineral and vitamin sources beneficial for the growth and development of their breastfed babies. They provide tasty flavor and satisfaction because of their interesting color, flavor and texture (Muchtadi, 2000).

Breastfeeding mothers rarely consume leaf vegetables (Table 6). Spinach and kangkung are consumed twice a week whereas sawi, carrot, cabbage and cassava leaf are consumed once a week. According to Rejeki (2000), types of vegetables frequently consumed by the households in Indonesia include spinach, cassava leaf, kangkung and genjer.

Spinach, kangkung, sawi, carrot, cabbage, long bean and melinjo leaf are mostly purchased. Cassava and papaya leaves are sometimes purchased or taken from their gardens or given by their neighbors.

Table 5. Statistics of Legumes Consumption Frequency of Breastfeeding Mothers

\begin{tabular}{|c|c|c|c|c|c|}
\hline \multirow[t]{2}{*}{ Kinds of Nuts } & \multirow[t]{2}{*}{$\mathbf{n}$} & \multirow[t]{2}{*}{$\%$} & \multicolumn{3}{|c|}{$\begin{array}{l}\text { Frequency of Consumption } \\
\text { (times per) }\end{array}$} \\
\hline & & & Month & Week & Day \\
\hline Tofu & 98 & 98.0 & 16.3 & 3.7 & 0.5 \\
\hline Tempeh & 97 & 97.0 & 14.9 & 3.5 & 0.5 \\
\hline Oncom (Traditional Indonesian Fermented Food) & 76 & 76.0 & 4.1 & 0.9 & 0.1 \\
\hline Peanut (Arachis hypogaea) & 76 & 76.0 & 3.9 & 0.9 & 0.1 \\
\hline Mung-bean (Phaseolus vulgaris) & 81 & 81.0 & 4.3 & 1.0 & 0.1 \\
\hline Cowpea (Vigna unguiculata L.) & 4 & 4.0 & 0.2 & 0.04 & 0.01 \\
\hline
\end{tabular}


Table 6. Statistics of Leaf Vegetables Consumption Frequency of Breastfeeding Mothers

\begin{tabular}{|l|r|r|r|r|r|}
\hline \multirow{2}{*}{ Kinds of Leaf Vegetables } & \multirow{2}{*}{$\mathbf{n}$} & \multirow{2}{*}{$\%$} & \multicolumn{3}{c|}{$\begin{array}{c}\text { Frequency of Consumption } \\
\text { (times per) }\end{array}$} \\
\cline { 5 - 6 } & & & \multicolumn{1}{c|}{ Month } & \multicolumn{1}{c|}{ Week } & \multicolumn{1}{c|}{ Day } \\
\hline Spinach & 97 & 97.0 & 10.4 & 2.4 & 0.3 \\
\hline Kangkung (Ipomoea reptans) & 98 & 98.0 & 9.8 & 2.3 & 0.3 \\
\hline Carrot & 89 & 89.0 & 7.8 & 1.8 & 0.3 \\
\hline Sawi (Brassica rugosa) & 82 & 82.0 & 5.9 & 1.4 & 0.2 \\
\hline Cassava Leaves & 77 & 77.0 & 5.8 & 1.3 & 0.2 \\
\hline Cabbage & 83 & 83.0 & 5.2 & 1.2 & 0.2 \\
\hline Melinjo Leaves (Gnetum gnemon) & 71 & 71.0 & 3.4 & 0.8 & 0.1 \\
\hline Papaya Leaves & 40 & 40.0 & 2.8 & 0.6 & 0.1 \\
\hline Lettuce (Lactuca sativa L.) & 36 & 36.0 & 2.4 & 0.6 & 0.1 \\
\hline
\end{tabular}

Frequency of Fruit Vegetable. Vegetables are dietary fiber sources and contain a number of antioxidants which have an important role in maintaining body health (Muchtadi, 2000). These vegetables are rarely consumed (Table 7). Tomato is consumed 5 to 6 times a week or almost every day. Those consumed once a week include cucumber, pumpkin and long bean. In general, the darker the color of the vegetables, the greater the contents of iron and vitamin A will be (Harper, Deaton, \& Driskel, 1985). Iron and vitamin A are required by the breastfeeding mothers and their babies to obtain body immunity and eye health.

Fruit vegetables especially pumpkin, tomato, cucumber, eggplant and baby jackfruit and papaya are mostly purchased by the women (see Appendix 3). There are 5 to $10 \%$ respondents stating that baby jackfruit and papaya are given by other people.

Frequency of Fruit. Fruits are also sources of vitamins and minerals; however, they are not consumed every day by the breastfeeding mothers (Table 8 ). Fruits consumed 2 to 3 times per week include orange and banana because they are abundantly available (not seasonal fruits) and their prices are affordable. Papaya and guava are consumed only once a week

Fruits can be obtained by purchasing or by taking them from their own gardens or getting them from other people. Jackfruit and guava are mostly obtained from other people.

Table 8. Statistics of Fruits Consumption Frequency of Breastfeeding Mothers

\begin{tabular}{|l|c|r|r|r|r|}
\hline \multirow{2}{*}{ Kinds of Fruits } & \multirow{2}{*}{$\mathbf{n}$} & \multirow{2}{*}{$\%$} & \multicolumn{3}{|c|}{$\begin{array}{c}\text { Frequency of } \\
\text { Consumption } \\
\text { (times per) }\end{array}$} \\
\cline { 3 - 6 } & & & Month & Week & \multicolumn{1}{c|}{ Day } \\
\hline Orange & 95 & 95.0 & 13.5 & 3.1 & 0.45 \\
\hline Banana & 91 & 91.0 & 12.3 & 2.8 & 0.4 \\
\hline Papaya & 86 & 86.0 & 6.5 & 1.5 & 0.2 \\
\hline Guava & 72 & 72.0 & 3.1 & 0.7 & 0.1 \\
\hline Apple & 65 & 65.0 & 2.0 & 0.5 & 0.1 \\
\hline Mango & 78 & 78.0 & 1.7 & 0.4 & 0.1 \\
\hline Pineapple & 30 & 30.0 & 0.9 & 0.2 & 0.03 \\
\hline Jackfruit & 57 & 57.0 & 1.0 & 0.2 & 0.03 \\
\hline Hairyfruit & 90 & 90.0 & 0.1 & 0.03 & 0.0 \\
\hline
\end{tabular}

Table 7. Statistics of Fruit Vegetables Consumption Frequency of Breastfeeding Mothers

\begin{tabular}{|c|c|c|c|c|c|}
\hline \multirow[t]{2}{*}{ Kinds of Fruit Vegetables } & \multirow[t]{2}{*}{$\mathbf{n}$} & \multirow[t]{2}{*}{$\%$} & \multicolumn{3}{|c|}{$\begin{array}{c}\text { Frequency of Consumption } \\
\text { (times per) }\end{array}$} \\
\hline & & & Month & Week & Day \\
\hline Tomato & 98 & 98.0 & 25.2 & 5.8 & 0.8 \\
\hline Cucumber & 80 & 80.0 & 7.9 & 1.8 & 0.3 \\
\hline Pumpkin (Legenaria leucantha) & 86 & 86.0 & 6.6 & 1.5 & 0.2 \\
\hline Long-bean (Caj anus cajan) & 85 & 85.0 & 4.8 & 1.1 & 0.2 \\
\hline Eggplant & 62 & 62.0 & 2.6 & 0.6 & 0.1 \\
\hline Baby papaya & 35 & 35.0 & 1.5 & 0.4 & 0.05 \\
\hline Baby jackfruit & 42 & 42.0 & 1.1 & 0.3 & 0.04 \\
\hline
\end{tabular}


Frequency of Snack Foods. The snack foods generally contain carbohydrates; however, breastfeeding mothers do not consume them every day (Table 9). Fried snacks and fried banana are frequently consumed i.e. 3 to 4 times per week. Meatball and bakwan are consumed twice a week. Snack foods are generally consumed only as supplementary foods and do not contain sufficient nutritional value. Such snacks as meatball, siomay, fried banana, chicken noodle, and other fried snacks are usually purchased from the small shops or from the traveling salesmen.

Frequency of Miscellaneous Foods. The miscellaneous foods consumed 5 to 7 times per week by the breastfeeding mothers include sugar, tea, and monosodium glutamate (MSG) (see Table 10). Coffee and crackers are consumed 4 times a week whereas soybean ketchup and sauce are consumed 1 to 3 times per week. As the snacks, these foods are usually purchased by the women.

\section{Consumption and Nutritional Adequacy of Babies}

Energy. The first and major food of babies is their mothers' breast milk containing complete nutrition as well as anti-infection substance for them. Nutrition consumption among babies in this research is exclusively from their mothers because they are only 0 to
11 months old. The consumption and energy adequacy level among babies are presented at Tables 11 and 12.

Table 11. Statistics of Nutrients Consumption of Breastfed Babies

\begin{tabular}{|l|r|r|}
\hline \multirow{2}{*}{ Nutrients } & \multicolumn{2}{|c|}{$\mathbf{n = 1 0 0}$} \\
\cline { 2 - 3 } & \multicolumn{1}{|c|}{ Mean } & \multicolumn{1}{c|}{ Std } \\
\hline Energy (kkal) & 667 & 506 \\
\hline Protein (gram) & 14.5 & 12.2 \\
\hline Vitamin A $(\mu g R E)$ & 496 & 413 \\
\hline Vitamin C $(\mathrm{mg})$ & 38 & 47.0 \\
\hline Vitamin B1 $(\mathrm{mg})$ & 0.2 & 0.16 \\
\hline Calcium $(\mathrm{mg})$ & 388 & 413 \\
\hline Phosfor $(\mathrm{mg})$ & 613 & 329 \\
\hline Iron $(\mathrm{mg})$ & 4.9 & 8.7 \\
\hline
\end{tabular}

Table 12. Statistics of Nutritional Adequacy of Breastfed Babies

\begin{tabular}{|l|r|r|}
\hline \multirow{2}{*}{ Nutrients } & \multicolumn{2}{|c|}{$\mathbf{n = 1 0 0}$} \\
\cline { 2 - 3 } & \multicolumn{1}{|c|}{ Mean } & \multicolumn{1}{c|}{ Std } \\
\hline Energy (\%) & 100.9 & $\mathbf{7 1 . 8}$ \\
\hline Protein (\%) & 106.8 & 86.1 \\
\hline Vitamin A (\%) & 141.6 & 118.2 \\
\hline Vitamin C (\%) & 118.5 & 142.1 \\
\hline Vitamin B1 (\%) & 59.0 & 43.3 \\
\hline Calcium (\%) & 113.5 & 115.4 \\
\hline Phosfor (\%) & 279.3 & 148.6 \\
\hline Iron (\%) & 122.6 & 207.0 \\
\hline
\end{tabular}

Table 9. Statistics of Snack Foods Consumption Frequency of Breastfeeding Mothers

\begin{tabular}{|l|r|r|r|r|r|}
\hline \multirow{2}{*}{ Kinds of Snacks } & \multirow{2}{*}{$\mathbf{n}$} & \multirow{2}{*}{$\%$} & \multicolumn{3}{c|}{$\begin{array}{r}\text { Frequency of Consumption } \\
\text { (times per) }\end{array}$} \\
\cline { 4 - 6 } & & & Month & \multicolumn{1}{c|}{ Week } & \multicolumn{1}{c|}{ Day } \\
\hline Fried food & 94 & 94.0 & 19.3 & 4.5 & 0.6 \\
\hline Fried Banana & 87 & 87.0 & 14.4 & 3.3 & 0.5 \\
\hline Bakwan (Fried Vegetables) & 75 & 75.0 & 10.4 & 2.4 & 0.3 \\
\hline Meatball & 94 & 94.0 & 9.1 & 2.1 & 0.3 \\
\hline Siomay (Kind of Chinese Foods) & 61 & 61.0 & 3.1 & 0.7 & 0.1 \\
\hline Chicken Noodle & 57 & 57.0 & 2.4 & 0.6 & 0.1 \\
\hline
\end{tabular}

Table 10. Statistics of Miscellaneous Foods Consumption Frequency of Breastfeeding Mothers

\begin{tabular}{|c|c|c|c|c|c|}
\hline \multirow{2}{*}{ Kinds of Miscellaneous Food } & \multirow[t]{2}{*}{$\mathbf{n}$} & \multirow{2}{*}{$\%$} & \multicolumn{3}{|c|}{$\begin{array}{l}\text { Frequency of Consumption } \\
\text { (times per) }\end{array}$} \\
\hline & & & Month & Week & Day \\
\hline Sugar & 98 & 98.0 & 24.0 & 5.5 & 0.8 \\
\hline Tea & 85 & 85.0 & 21.6 & 5.0 & 0.7 \\
\hline Coffee & 73 & 73.0 & 18.0 & 4.2 & 0.6 \\
\hline Sauce & 50 & 50.0 & 5.5 & 1.3 & 0.2 \\
\hline Kerupuk (Crackers) & 93 & 93.0 & 18.5 & 4.3 & 0.6 \\
\hline Vetsin/MSG & 96 & 96.0 & 28.4 & 6.6 & 0.9 \\
\hline Soybean Ketchup & 87 & 87.0 & 12.6 & 2.9 & 0.4 \\
\hline
\end{tabular}


The sufficient energy requirement of one year for babies varies according to their age and weight. In general, for their first six month of life, they require $115-120 \mathrm{kcal} /$ day; however, this requirement will be less, i.e. around 105 to $110 \mathrm{Kcal} /$ day when they are over 6 months old (Arisman, 2004). The average energy consumption is $667 \mathrm{Kcal} /$ day where this has reached $100 \%$ of the recommend energy level (RDA) (Table 12).

Protein. The biological value of mothers' breast milk is higher than other proteins. Based on weight, a baby's requirement of protein is $2.3 \mathrm{~g} / \mathrm{kg} /$ day and $2 \mathrm{~g} / \mathrm{kg} /$ day at the age of less than 6 months and over six months respectively (Arisman, 2004).

From Table 11 and 12, it can be seen that the average consumption of protein is $14.5 \mathrm{~g} /$ day, and this has fulfilled $106 \%$ of the recommended protein level.

Calcium. Calcium is very crucial for babies' growth especially for bone and tooth formation. The consumption is relatively sufficient, i.e. $388 \mathrm{mg} /$ day, and this has met $113 \%$ of the recommended calcium level (Table 12).

Phosphor. Phosphor is also crucial for the physical growth of babies. As a whole, the consumption of phosphor is $613 \mathrm{mg} /$ day, and this has met $279 \%$ of the recommended phosphor level.

Iron. Consumption and iron (Fe) adequacy level of the infants are presented at Table 11 and 3.22. From Table 11, it can be seen that the average consumption of protein is $4.9 \mathrm{~g} /$ day. With the assumption of $15 \%$ iron absorption, the adequacy level of iron for babies has exceeded the recommended level.

Vitamin A. In general, the average consumption of vitamin $A$ is 496 ugRE or has reached $114 \%$ of the recommended vitamin A level. The consumption relatively varies as shown by the standard deviation of $413 \mathrm{mg}$.

Vitamin C. In general, the average consumption of vitamin $\mathrm{C}$ is $38 \mathrm{mg}$ and has exceeded the recommended vitamin C level.

Vitamin B1. As a whole, the average vitamin B1 consumption of the infants is 0.20 $\mathrm{mg}$ or only fulfills $59 \%$ of the recommended vitamin B1 level. The consumption is relatively the same as shown by the standard deviation of $0.16 \mathrm{mg}$.

\section{Nutritional Status of Breastfeeding Mothers and Infants}

\section{Nutritional Status of Breastfeeding Mothers}

The nutritional status of breastfeeding mothers is determined by using the body mass index (BMI), which is then classified according to WHO categories (1995). Based on the data presented in Figure 1 and Table 13, the prevalence of breastfeeding mothers in the thin category is $10 \%$. The low BMl is significantly related to the quantity and quality of breast milk and the problem of infant's growth. The breastfeeding mothers also suffer from over nutrition. The prevalence of overweight (BMI>25) breastfeeding mothers is $16 \%$.

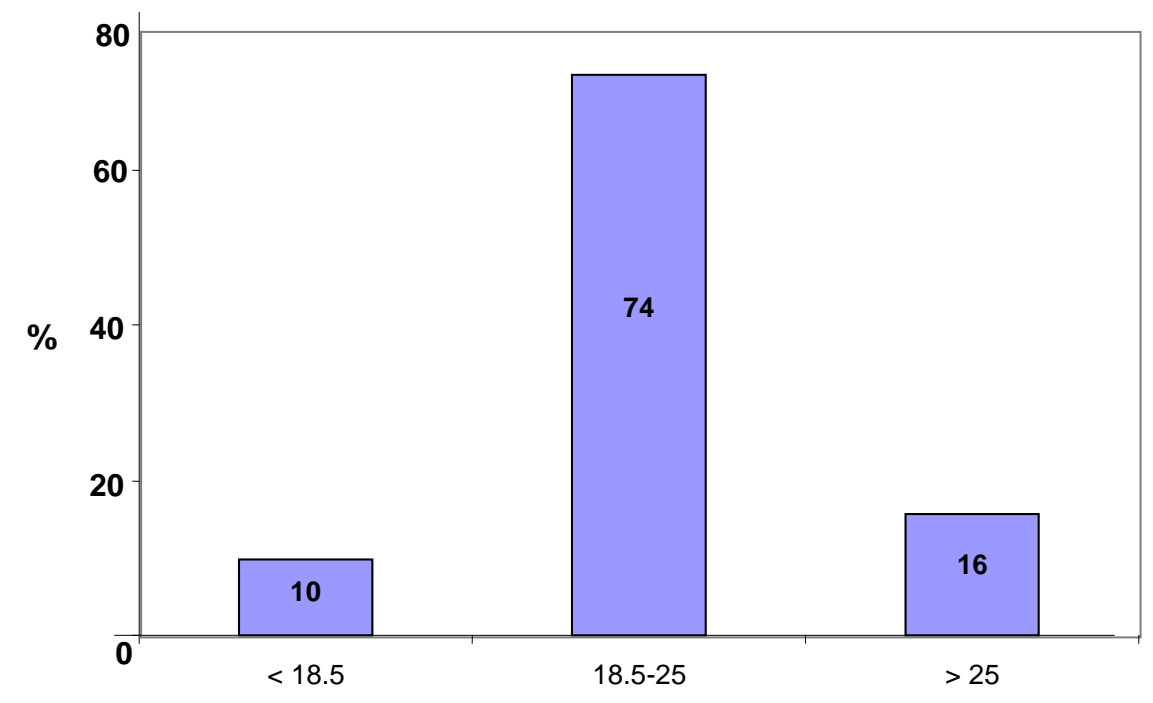

Figure 1. BMI Category of Breastfeeding Mother 
Table 13. Distribution of Breastfeeding Mothers based on IMT Category

\begin{tabular}{|l|l|c|c|}
\hline \multicolumn{1}{|c|}{ IMT Category } & $\begin{array}{c}\text { IMT } \\
\text { Value }\end{array}$ & $\mathbf{n}$ & $\%$ \\
\hline Thin & $<18.5$ & 10 & 10.0 \\
\hline Normal & $18.5-25$ & 74 & 74.0 \\
\hline Overweight & $>25$ & 16 & 16.0 \\
\hline
\end{tabular}

\section{Nutritional Status of Infants}

Anthropometric Characteristics. These characteristics, consisting of age, body weight, and height, are presented in Table 14. The average age of infants in the research location on the whole is $5.8 \pm 3.1$ months, with the lowest of 1 month and the highest of 11 months. On the whole, the average bodyweight of infants is $6.8 \pm 1.5 \mathrm{~kg}$, with the lowest weight of $3.5 \mathrm{~kg}$ and the highest weight of $10.0 \mathrm{~kg}$. The average body length of infants as a whole is $62.2 \pm 7.0 \mathrm{~cm}$, the lowest length of $45.5 \mathrm{~cm}$ and the highest of $80.0 \mathrm{~cm}$.

Table 14. Statistics of Breastfed Infants' Anthropometric

\begin{tabular}{|l|r|r|r|r|}
\hline Characteristics & \multicolumn{1}{|c|}{ Mean } & \multicolumn{1}{c|}{ Std } & \multicolumn{1}{c|}{ Min } & \multicolumn{1}{c|}{ Max } \\
\hline Age (month) & 5.8 & 3.1 & 1.0 & 11.0 \\
\hline Weight $(\mathrm{kg})$ & 6.8 & 1.5 & 3.5 & 10.0 \\
\hline Height $(\mathrm{cm})$ & 62.2 & 7.0 & 45.5 & 80.0 \\
\hline
\end{tabular}

Weight for Age (W/A). The prevalence of malnutrition is determined based on the number of children whose anthropometric index is below -2 SD (Jahari, 2002). The weight for age (W/A) shows a generally hindered growth, but less specific for identifying a chronic and acute malnutrition problem. Based on the resulted calculation of Z-score of W/A for infants with the threshold point of $<$ 2SD for underweight, the underweight prevalence is found to be $8.5 \%$ (Table 15), including the prevalence of severe underweight (Z-score <- 3 SD), i.e. $4.1 \%$. The prevalence of overweight infants is very low, i.e. $1.1 \%$.

Table 15. Distribution of Breastfed Infants according to W/A Z-score

\begin{tabular}{|l|c|c|}
\hline \multicolumn{1}{|c|}{ W/A Z-score } & $\mathbf{n}$ & $\%$ \\
\hline $\mathrm{Z}<-2$ & 8 & 8.5 \\
\hline Normal & 85 & 90.4 \\
\hline $\mathrm{Z}>+2$ & 1 & 1.1 \\
\hline
\end{tabular}

From Figure 2 it is clearly seen that the median Z-score of W/A for the children in the research location is further away to the left than the WHO standard of 2005. The median Zscore for the children in this area is approaching the standard deviation of -0.5 .

The gender-based analysis shows the curve of the Z-score for male infants is worse than that for female infants (see Figure 3). The underweight prevalence among male infants is $10.9 \%$, which is much higher than that among female infants (5.8\%). In terms of age groups from Figure 6.4 it can be seen that the Z-score of W/A is almost the same between the age groups of $0-5$ months and of $6-11$ months.

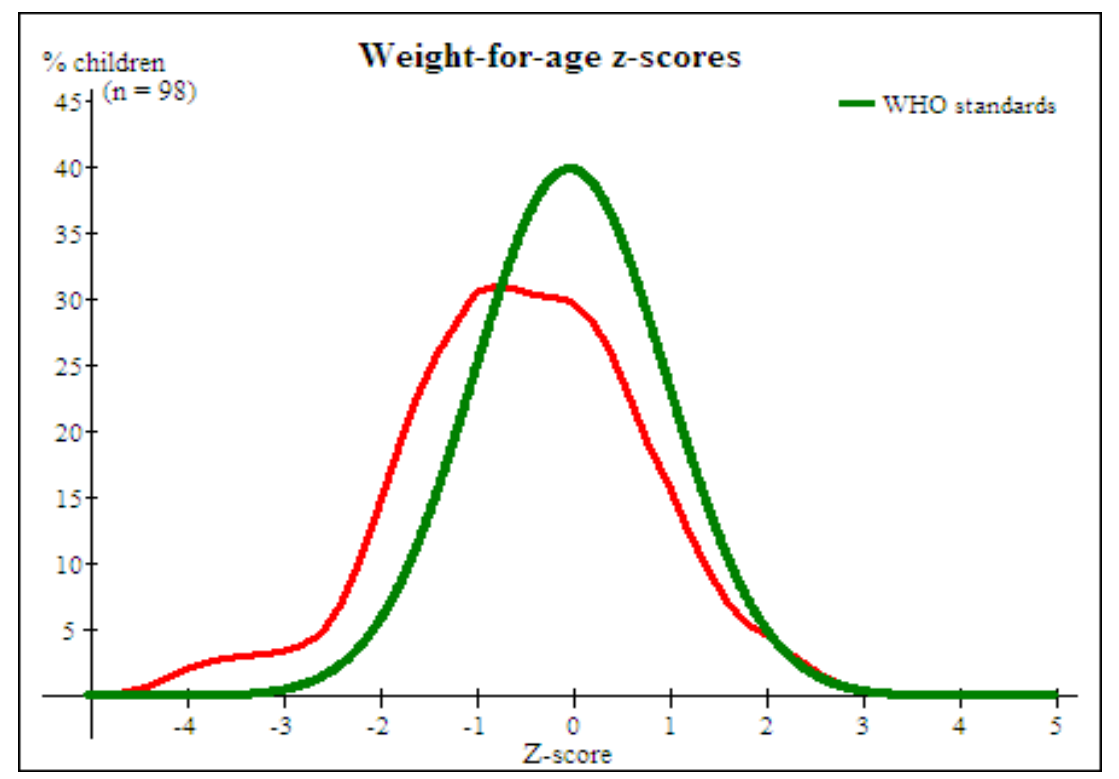

Figure 2. Distribution of Breastfed Infants based on W/A Z-score 


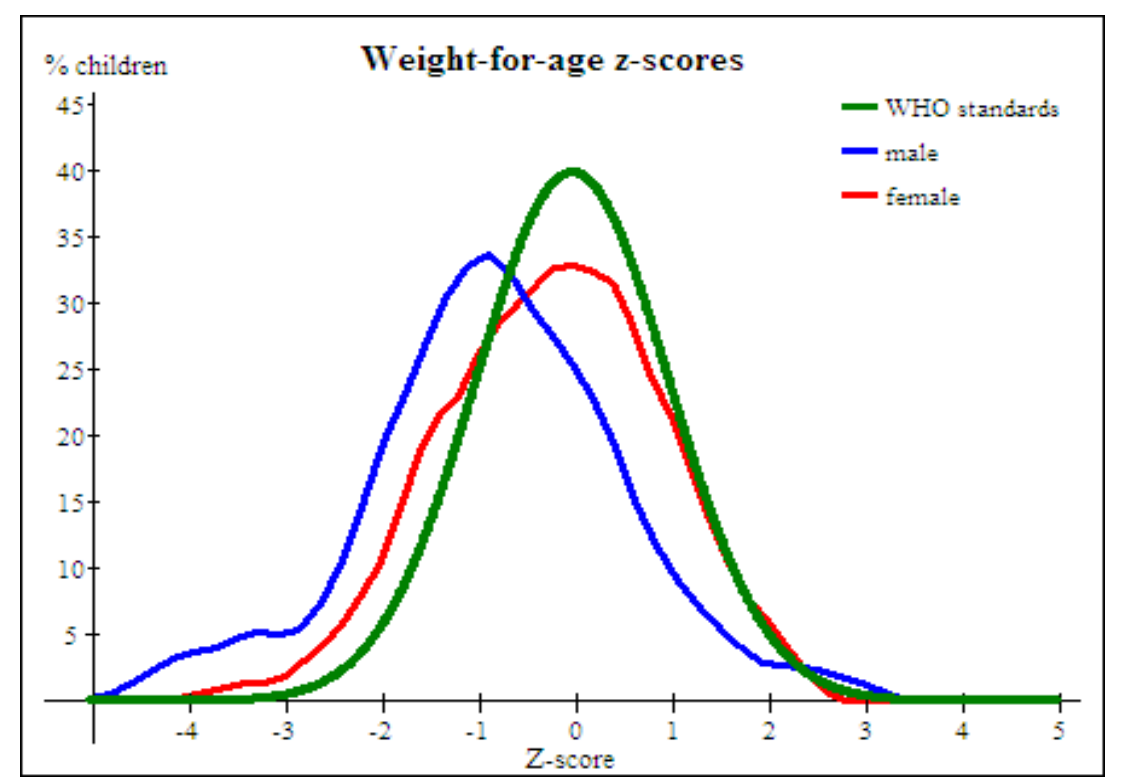

Figure 3. Distribution of Breastfed Infants based on W/A Z-score and Sex

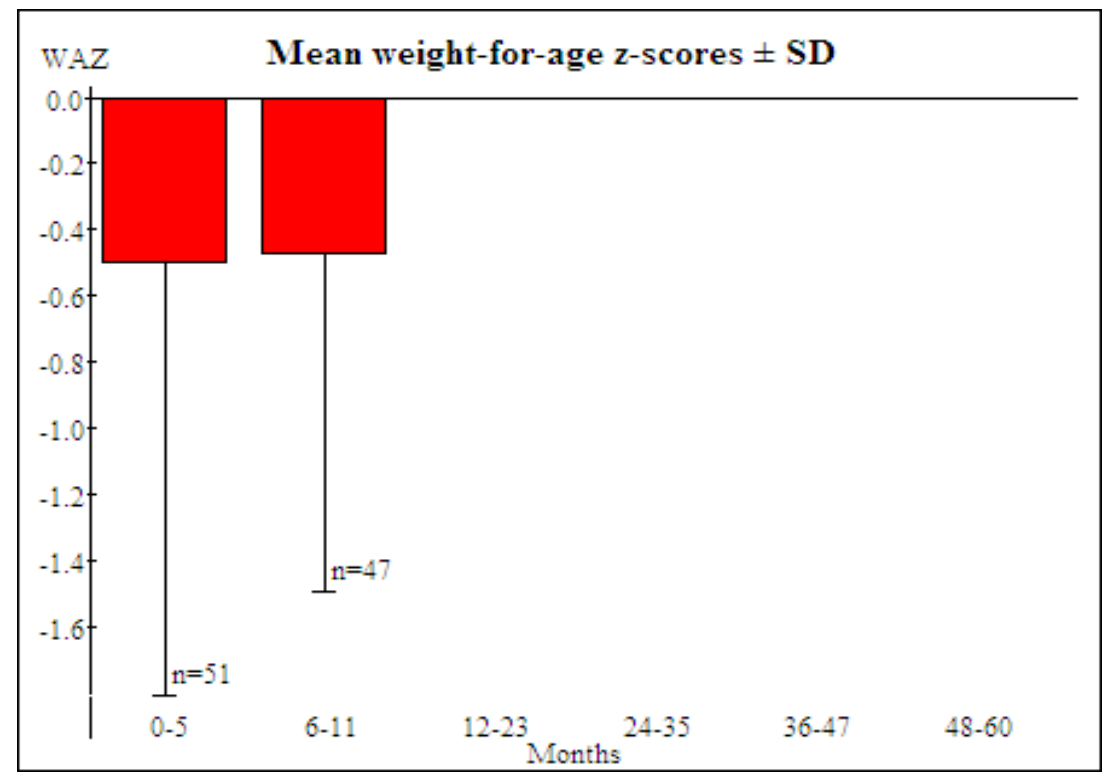

Figure 4. W/A Z-score Value of Breastfed Infants based on Age Group

Height for Age (H/A). In the first year of living, the height of infants increase by $50 \%$, but it does not double as age increases until the age of 4 years. The stunted prevalence as a whole is $45.7 \%$. This prevalence is approaching the stunted prevalence in Indonesia 5-6 years ago.

The prevalence of severe stunted (with the criteria $<-3 \mathrm{SD}$ ) among infants is $21.1 \%$. From Figure 5, it is clearly seen that the median Z-score of H/A among children in the research location is much further to the left than NCHS/WHO standards. The median Z- score of $\mathrm{H} / \mathrm{A}$ for children in this area has exceeded the standard deviation of -2 or stunting.

Table 16. Distribution of Breastfed Infants according to H/A Z-score

\begin{tabular}{|l|r|r|}
\hline \multicolumn{1}{|c|}{ H/A Z-score } & \multicolumn{1}{c|}{ n } & \multicolumn{1}{c|}{$\%$} \\
\hline$Z<-2$ & 43 & 45.7 \\
\hline Normal & 47 & 50.0 \\
\hline$Z>+2$ & 4 & 4.3 \\
\hline
\end{tabular}




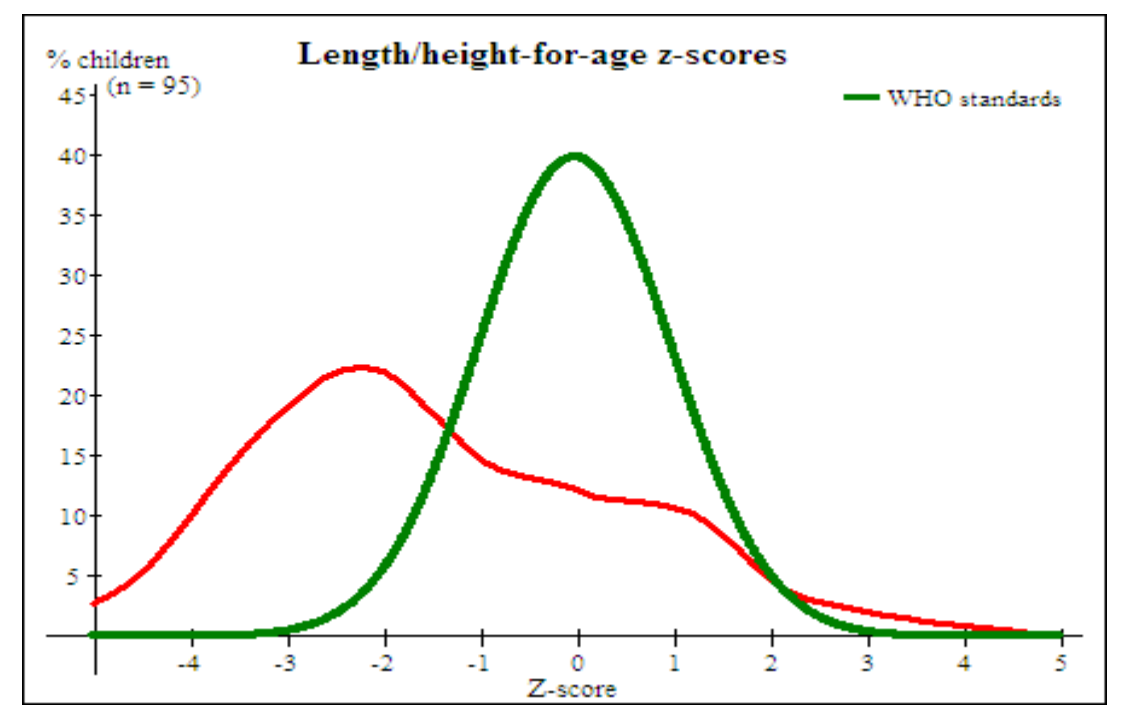

Figure 5. Distribution of Breastfed Infants based on H/A Z-score

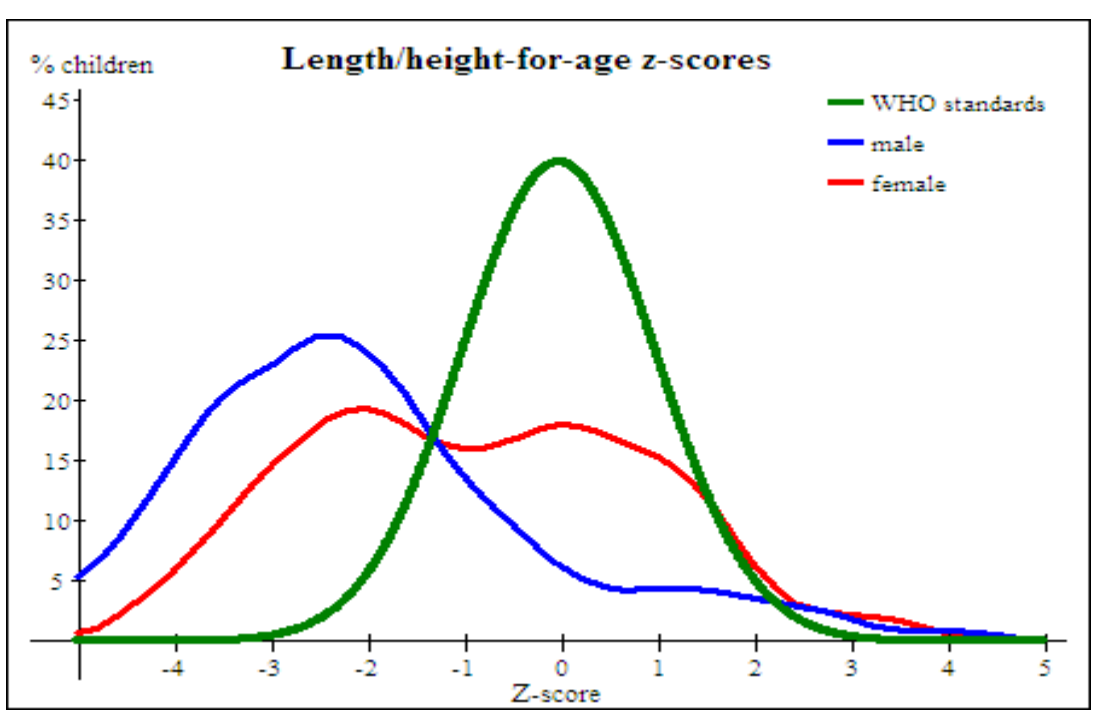

Figure 6. Distribution of Breastfed Infants based on H/A Z-score and Sex

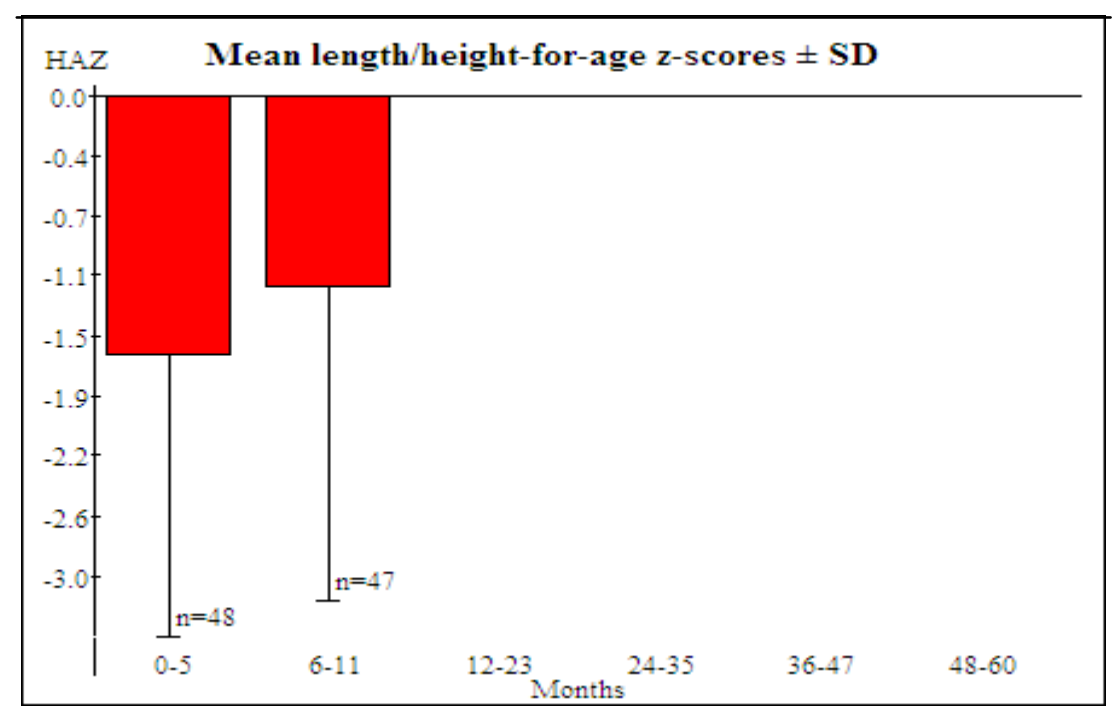

Figure 7. H/A Z-score Value of Breastfed Infants based on Age Group 
The gender-based analysis shows that the curve for the Z-score of H/A among the boys is worse than that among the girls (see Figure 6). Stunted prevalence among male infants $(59.1 \%)$ is higher than it is among female infants (33.3\%). From Figure 7 it can be seen that the Z-score of H/A is worse in the age group of $0-5$ months than in the age group of 6-11 months.

Weight for Height $(\mathrm{W} / \mathrm{H})$. This index shows the picture of an acute problem of nutrition (Jahari, 2002). Based on the resulted calculation of the Z-score for $\mathrm{W} / \mathrm{H}$ index with the criteria of wasted < - 2 SD, wasted prevalence is found to be $9.6 \%$ among infants (Table 17). The prevalence of severe wasted (Z- score <-3 SD) in this research is quite low, i.e. $7.9 \%$.

Table 17. Distribution of Breastfed Infants according to W/H Z-score

\begin{tabular}{|l|r|r|}
\hline \multicolumn{1}{|c|}{ W/H Z-score Category } & \multicolumn{1}{c|}{ n } & \multicolumn{1}{c|}{$\%$} \\
\hline$Z<-2$ & 9 & 9.6 \\
\hline Normal & 59 & 62.8 \\
\hline$Z>+2$ & 26 & 27.7 \\
\hline
\end{tabular}

From Figure 8 it is clearly seen that the curve for Z-score of $\mathrm{W} / \mathrm{H}$ among infants in the research location is wider than the WHO standard of 2005. The median Z-score of $\mathrm{W} / \mathrm{H}$ for infants in this location is getting closer to the standard deviation of 0.5 .

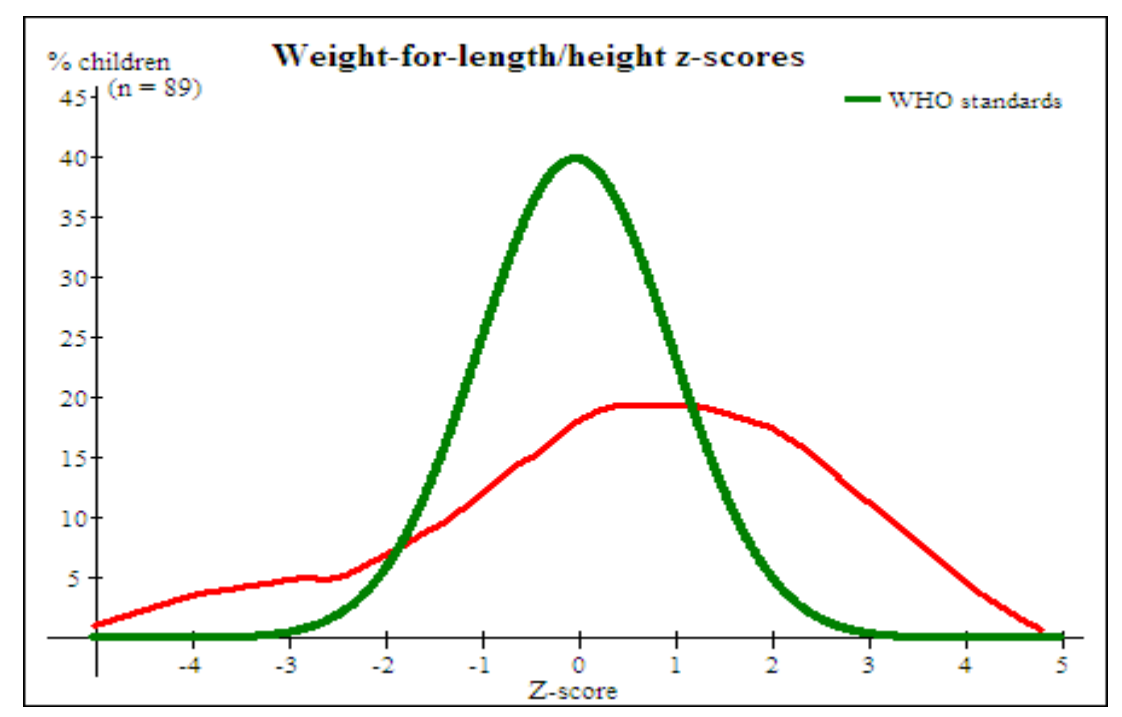

Figure 8. Distribution of Breastfed Infants based on W/H Z-score

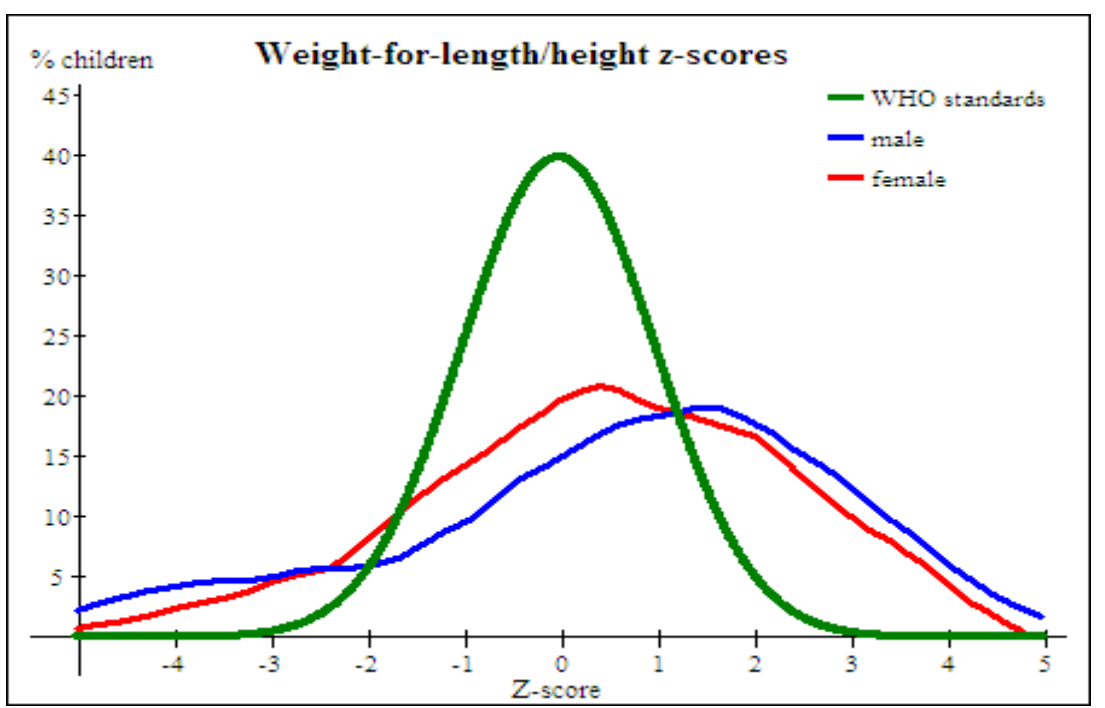

Figure 9. Distribution of Breastfed Infants based on W/H Z-score and Sex 


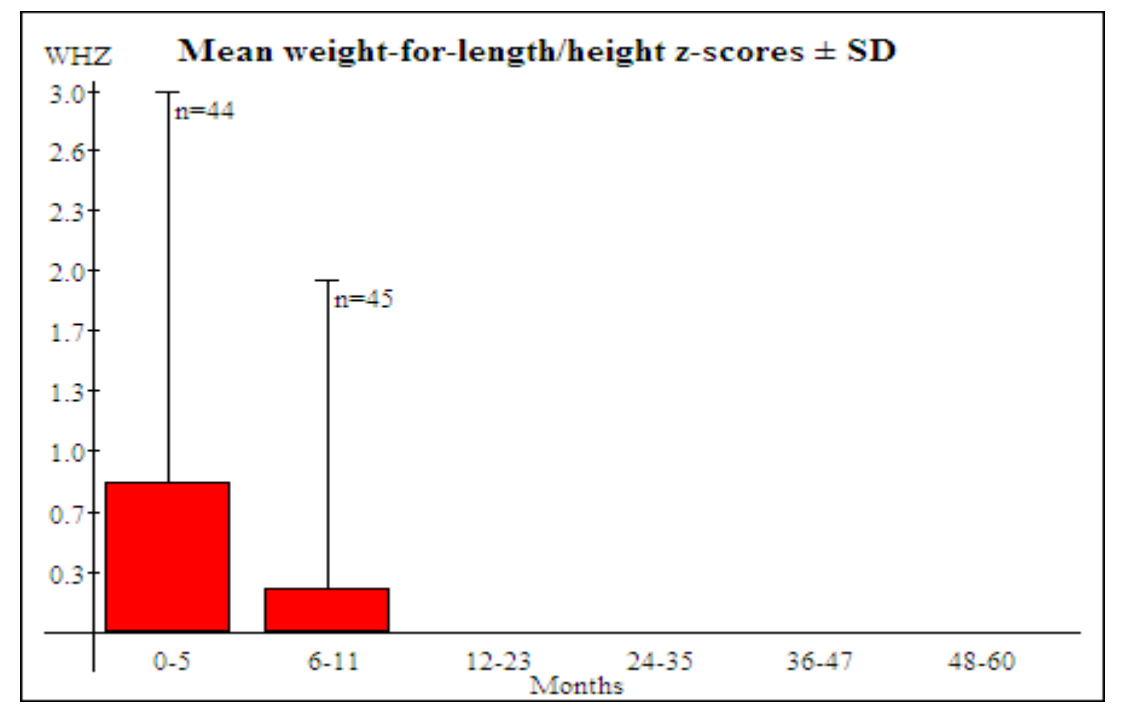

Figure 10. W/H Z-score Value of Breastfed Infants based on Age Group

The gender-based analysis indicates that the curve for the Z-score of $\mathrm{W} / \mathrm{H}$ among female infants is slightly worse than it is among male infants (see Figure 9). The wasted prevalence among male infants $(12.8 \%)$ is higher than that among female infants $(8.0 \%)$. Figure 10 shows that the $\mathrm{Z}$-score of $\mathrm{W} / \mathrm{H}$ for the age group of $0-5$ months is better than that for the age group of 6-11 months.

\section{CONCLUSION AND RECOMMENDATION}

\section{Conclusion}

The energy and protein consumption of breastfeeding mothers reaches only $60 \%$ and $87 \%$ of the RDA, the average consumption of energy and protein among infants is $100 \%$ and $106 \%$ of the RDA respectively.

The prevalence of breastfeeding mothers in the thin category is $10 \%$. The breastfeeding mothers also suffer from over nutrition. The prevalence of overweight (BMI>25) breastfeeding mothers is $16 \%$. Based on the resulted calculation of Z-score of W/A for infants with the threshold point of $<-2$ SD for underweight, the underweight prevalence is found to be $8.5 \%$, including the prevalence of severe underweight (Z-score <- $3 \mathrm{SD}$ ), i.e. $4.1 \%$. The prevalence of overweight infants is very low, i.e. $1.1 \%$. Based on the resulted calculation of the Z-score for $\mathrm{H} / \mathrm{A}$ the height of infants increase by $50 \%$. The stunted prevalence as a whole is $45.7 \%$. The prevalence of severe stunted (with the criteria < -3 SD) among infants is $21.1 \%$. Based on the resulted calculation of the Z-score for $\mathrm{W} / \mathrm{H}$ index with the criteria of wasted $<-2 \mathrm{SD}$, wasted prevalence is found to be $9.6 \%$ among infants. The prevalence of severe wasted (Z-score <-3 SD) in this research is quite low, i.e. $7.9 \%$.

\section{Recommendationn}

1. The energy and protein consumption of breastfeeding mothers must be increased to fulfill of the recommended dietary allowances.

2. Because the mother's milk is very important for babies, so the breastfeeding mother must give a good breastfeeding practice for the period of six months followed by the introduction of other foods. This is important to improve/maintain good nutritional status of babies.

\section{ACKNOWLEDGEMENT}

Appreciation and gratitude to the Neysvan Hoogstraten Foundation (NHF), the Netherlands for supporting and funding this research. And thank you to other research team Ali Khomsan, Hadi Riyadi, and Faisal Anwar from Department of Community Nutrition, Faculty of Human Ecology, Bogor Agricultural University.

\section{BIBLIOGRAPHY}

Ariani M, Erwidodo \& A Purwoto. 1998. Rice Consumption: Its Implication towards Availability. Journal of Nutrition and Family. 
Arisman. 2004. Nutrition in Life Cycles: Text Book of Nutrition Science. Medical Book Publisher EGC. Jakarta.

Azwar A. 2004. Aspects of Health and Nutrition in Food Security. Paper of National Workshop on Food and Nutrition 2004. LIPI (Indonesian Institute of Science). Jakarta.

Erwidodo, M Ariani \& A Purwoto. 1997. Consumption Development and Project- ion of Rice Demand in Indonesia. Journal of Agro Economy, 16 (1 \& 2), 60-67.

Harper IJ, BJ Deaton, \& JA Driskel. 1986. Food, Nutrition, and Agriculture (Suhardjo, translator) $\left(2^{\text {nd }} E d.\right)$. UI Press, Jakarta.

Jahari AB. 2002. Manual Book of Nutritional Status Evaluation Methods. Centre of Food and Nutrition Research - Research and Development Agency, Department of Health, Republic of Indonesia, Jakarta.

Maxwell S \& TR Frankenberger. 1992. Household Food Security: Concepts, Indicators, easurements, A Technical Review. Rome: International Fund for Agricultural Development/United Nations Children's Fund.
Muchtadi D. 2000. Vegetables as Sources of Fibre and Antioxidants: Preventing of Degenerative Diseases. Faculty of Agricultural Technology, Bogor Agricultural University (IPB), Bogor.

Rejeki AS. 2000. Food Habits of Vegetable Consumption on Girl Teenager in Urban Area. Undergraduate script (unpublished). Department of Community Nutrition and Family Resources, Faculty of Agriculture, Bogor Agricultural University (IPB), Bogor.

Susmaji K. 2004. Energy Consumption, Protein, and Nutritional Status of $1^{\text {st }}$ Grade Students of Elementary School in Poor and Non-Poor Village of Payakumbuh Sub-district, Lima Puluh Koto Regency, West Sumatera Province. Undergraduate script (unpublished). Department of Community Nutrition and Family Resources, Faculty of Agriculture, Bogor Agricultural University (IPB), Bogor.

Walker WA. 1988. Discussion: Part II. Birth from the National Point of View. A Nutrition in the Postpartum Period. In Prenatal Nutrition. Lindblad BS, editor. New York: Academic. Pages 193-197. 